\title{
Linking Emotional Brand Attachment and Sales Promotion to Post-Purchase Cognitive Dissonance: The Mediating Role of Impulse Buying Behavior
}

\author{
Muhammad Imad Ud Din AKBAR ${ }^{1}$, Bilal AHMAD², Mirza Huzaifa ASIF ${ }^{3}$, Shahid Ali SIDDIQUI ${ }^{4}$
}

Received: August 01, 2020 Revised: September 28, 2020 Accepted: October 05, 2020

\begin{abstract}
The primary objective of this research is to develop a better understanding of consumer's post-purchase psychological state by examining the influence of sales promotion and emotional brand attachment on post-purchase cognitive dissonance, taking into account the mediating role of impulse buying behavior. The current study addresses several gaps in literature. Firstly, it is hard to find the direct impact of sales promotion and emotional brand attachment on post-purchase cognitive dissonance. Secondly, to the best of our knowledge, few studies have investigated the mediating role of impulse buying behavior in consumer research. A sample of 256 respondents was collected from Pakistani retail consumers. The statistical findings of this study show that sales promotion has a significant positive effect on the impulse buying behavior and post-purchase cognitive dissonance. Furthermore, results indicate that emotional brand attachment has a negative influence on impulse buying behavior but has a significant positive impact on post-purchase cognitive dissonance. Meanwhile, impulse buying behavior is a potential mediator between sales promotion, emotional brand attachment, and post-purchase cognitive dissonance relationships. The moderating role of Gender describes that the positive relationship between sales promotion and post-purchase cognitive dissonance will be stronger for women as compared to men at a higher level of sales promotion.
\end{abstract}

Keywords: Sales Promotion, Emotional Brand Attachment, Impulse Buying Behavior, Post-Purchase Cognitive Dissonance, Retail Brands

JEL Classification Code: M10, M30, M31

\section{Introduction}

As the competitive business environment is increasing, the impulse buying behavior signifies an effective marketing strategy and is considered as an important element in the retail sales and e-commerce sector (Hausman, 2000;

${ }^{1}$ First Author. Assistant Professor, Department of Management Sciences, National University of Modern Languages, Pakistan. Email: dr.imad@numl.edu.pk

${ }^{2}$ Corresponding Author. PhD Scholar, School of Economics and Management, North China Electric Power University, China [Postal Address: Military Accounts Colony, Alfentry Road, Dharampura Mustafabad 39571 Lahore Punjab, Pakistan] Email: bilalahmad12382@yahoo.com

${ }^{3} \mathrm{PhD}$ Scholar, School of Economics and Management, North China Electric Power University, China. Email: mirzahuzaifa1@gmail.com ${ }^{4} \mathrm{PhD}$ Scholar, School of Economics and Management, North China Electric Power University, China. Email: nice.shahidsiddiqui@gmail.com

(c) Copyright: The Author(s)

This is an Open Access article distributed under the terms of the Creative Commons Attribution Non-Commercial License (https://creativecommons.org/licenses/by-nc/4.0/) which permits unrestricted non-commercial use, distribution, and reproduction in any medium, provided the original work is properly cited.
Parboteeah et al., 2009; Vohs \& Faber, 2007). Based on prior research it is evident that impulse purchases are affected by mood (Bozaci, 2020). Such purchasing behavior can also have possible disadvantages for consumers (Helga, 2001). The question of how to manage impulse buying behavior has become a vital topic for researchers, practitioners, and consumers themselves. However, few studies have investigated the mediating role of impulse buying behavior in consumer research. Thus, the current study addresses this gap in literature by examining impulse buying behavior as a potential mediator for the relationship among sales promotion, emotional brand attachment, and post-purchase cognitive dissonance. A more in-depth understanding of impulse buying behavior concept is therefore clearly needed in the interest of theoretical knowledge and ethical marketing practices. The previous literature shows that sales promotion expenditure has been a significant marketing spending and makes an impact on consumer buying behavior (Blattberg \& Neslin, 1990; Hartley \& Cross, 1988). Prior literature has investigated the relationship of sales promotion with brand equity, customer satisfaction, and advertising. According to 
Vongurai (2020), consumers usually create more preference for brands when their association with a specific brand is increased and it may affect their purchasing decision. In this study, we have examined the impact of sales promotion on the impulse buying behavior and post-purchase cognitive dissonance. According to the author's knowledge, no previous study has examined the direct relationship between sales promotion and post-purchase cognitive dissonance.

In the past three decades, the impact of emotions on consumer behavior has increased according to the branding scholars. Previous researches have claimed that consumers can emotionally connect to both possessions and brands (Chaudhuri \& Holbrook, 2001; Ball \& Tasaki, 1992; Sivadas \& Venkatesh, 1995; Straker \& Wrigley, 2016) and that emotional attachment with brands influences purchase intentions, attitude, and loyalty (Matzler et al., 2006; Park et al., 2010).

The current study observed the impact of emotional brand attachment on the impulse buying behavior and post-purchase cognitive dissonance. Since emotional brand attachment is a possible distal antecedent, the relationship between emotional brand attachment and post-purchase cognitive dissonance has been less explored in marketing literature. Meanwhile, post-purchase cognitive dissonance always happens by some regret, discomfort, and sorrow in the customer's mind, emotional branding with touching a chord and positive views can make a perfect connection with the product. Therefore, it is vital for marketers to use emotional branding as a strategic tool to overcome the customer's post-purchase cognitive dissonance. Specifically, post-purchase cognitive dissonance is not favorable for marketers, when consumers purchase their brands and feel a sense of guilt about buying them. In consumer behavior literature, post-purchase regret is raised by low-consumer satisfaction (Inman et al., 1997; Taylor \& Schneider, 1989). Based on the above discussion, the primary objective of this research is to examine the impact of sales promotion and emotional brand attachment on post-purchase cognitive dissonance, taking into account the mediator role of impulse buying behavior. So based on the above discussion, we believe that this study meaningfully contributes to the existing body of knowledge by observing this concept.

\section{Literature Review and Hypothesis Development}

\subsection{Sales Promotion and Post-Purchase Cognitive Dissonance}

Sales promotion is an effective marketing strategy, its purpose is to have a direct impact on consumer buying behavior (Blattberg \& Neslin, 1990). Sometimes, sales promotion is considered as a less important activity but companies are focusing on having well planned and structured sales promotions. Marketers should communicate to the consumers about what they have to offer (Jobber \& Lancaster, 2006). Chandon et al. (2000) suggested that sales promotion positively influences shopping behavior by providing useful benefits. Consumers lean towards purchases to enjoy more benefits. However, sales promotion also encourages unplanned purchases (Hui et al., 2013; Raghubir et al., 2004; Rook, 1987). There are several consequences which results from unplanned purchases such as budgetary infringement, disappointment, and a sense of guilt (Rook, 1987), i.e. consumers experienced negative service when evaluating a shopping experience of unplanned purchases (Hoch \& Loewenstein, 1991; Rook, 1987; Stilley et al., 2010). Although, previous studies (Festinger, 1957; Menasco \& Hawkins, 1978; Mowen, 1995), defined cognitive dissonance as a psychologically uncomfortable state which is associated with regret, anxiety, and doubt. This concept indicates that sales promotion may have the impact on post purchase cognitive dissonance. Hence, we proposed the following hypothesis.

H1: Sales promotion is significantly and positively related to post-purchase cognitive dissonance.

\subsection{Sales Promotion and Impulse Buying Behavior}

Stern (1962) defined impulse buying behavior as any purchase by the buyer that has not been planned. This kind of purchase is considered as an unexpected purchase, with no pre-shopping intentions either to buy any specific product type (Beatty \& Ferrell, 1998). An impulse buying behavior allows individuals to make an unreflective and instant purchase and feel a calling to buy the product (Jones et al., 2003; Rook, 1987). Sales promotion budget is decided by the organizations based on marketing spending that deserves more attention for marketers (Blattberg \& Neslin, 1990; Hartley \& Cross, 1988). The main objective of sales promotions is to have an immediate impact on consumer buying behaviors (Blattberg \& Neslin, 1990; Kotler, 1997). Sales promotion affects the purchase decisions of customers and it makes an impact on their behavior (Nagadeepa \& Selvi, 2015). Furthermore, Sinha \& Smith (2000) described "buy one get one free" is one of the useful sales promotional tools, which means if a customer buys a product, he/she will get the similar product for no price and the customer gives more preference to such offers to get another product for free. Therefore, consumers make impulse decisions to buy such deals. Similarly, discounts on the price, coupons, free samples, and bonus packs are similar tactics in sales promotions that enforce buyers to make impulse decisions (Ali Khan \& Sohaib Zubair, 2019). Hence, based on the above decision we proposed the following hypothesis.

H2: Sales promotion is significantly and positively related to impulse buying behavior. 


\subsection{Emotional Brand Attachment and Impulse Buying Behavior}

In psychology, attachment is known as the emotional bond between person and the object (Bowlby, 1977). In the marketing term, people can develop their emotional relationships with different brands (Belk, 1988; Fournier, 1998). Thus emotional brand attachment develops a bond that creates a connection between a customer and a particular brand and feeling toward the brand. These feelings involve passion, connection, and affection (Thomson et al., 2005). Recently, Kaufmann et al. (2016) defined that customers having greater attachment with a brand are more likely to purchase the product of that brand, original or fake. Kessous et al. (2015) argue that the emotional attachment of the brand has a connection to the sentimental status of the brand. Brands have this capability to evoke customer's nostalgic feelings by giving them a particular experience that he or she craves for (Loveland et al., 2010). If the brands have the capability to promote sentimental experiences then customers will be attached to these brands and it will increase their tendency to collect that particular brand item (Kessous et al., 2015). Past studies examined that the impulsive behavior of customers tends to show high emotional attachment with brands (Japutra et al., 2019) and they are more enthusiastic to spend money on these brands (C. W. Park et al., 2010). Thus we proposed the following hypothesis.

H3: Emotional brand attachment is significantly and negatively related to impulse buying behavior.

\subsection{Emotional Brand Attachment and Post- Purchase Cognitive Dissonance}

A study by Egan et al. (2007) states that "cognitive dissonance is one of the most debatable concepts in the literature of psychology. Although, cognitive dissonance has repeatedly been used to discuss post-purchase phenomena. It occurs after a purchase which is called post-purchase cognitive dissonance (Schiffman, 1997). It is described as an uncomfortable tension resulting from two conflicting thoughts at the same time. The famous psychologist Festinger (1957) was the first to develop the theory of cognitive dissonance. However, this theory can also be applied in the field of marketing. For instance, Bawa \& Kansal (2008) advised the marketers to help consumers to reduce cognitive dissonance by offering securities and warranties, improve service quality, and provide detailed information on how to use products correctly. Post-purchase cognitive dissonance and emotional brand attachment always depend on the basic principle of making a mark on human feelings. Marketers describe the shift of psychological states of consumers by using emotional branding as a battle line tool and touching the inside emotions of the customer which results in developing the relationship between brand and the post-purchase decision by the customer. From recent days marketers are likely to associate cognitive dissonance with the emotional brand attachment through their offerings and it is imperious for marketers to use emotional branding as a strategic tool to overcome cognitive dissonance (Jamwal \& Soodan, 2014). The tendency depends on the consumer's experiences, attachments, and feelings to purchase a new product in replacement of the old product they own. Attachment towards product/ brand could be comparatively strong or weak. Strong attachments are related to stronger feelings of connection, love, and passion (Mugge et al., 2010). Hence, this argument indicates the possibility for hypothesis development.

H4: Emotional brand attachment is significantly and negatively related to post-purchase cognitive dissonance.

\subsection{Impulse Buying Behavior and Post-Purchase Cognitive Dissonance}

Those individuals who are highly involved in the buying decision-making process, are likely to be more confident in their inflexible cognition that led to the final purchase (Mittal, 1989). They might believe that the intensive information search, collection, and analysis helps their pre-purchase cognition (Smith \& Bristor, 1994). Most of the impulse purchases are likely to go wrong when there is a lack of proper information about the product (Rook \& Fisher, 1995). Once the product is purchased this will cause an impulse buyer to re-think their purchase decision. However, there is another point to this view: impulse purchaser might have more risk taker and they are more likely to take the inconsistency in expected results for their purchases more lightly. The cognitive dissonance is one of the possible effects of impulse purchases (Festinger, 1957) or discomfort situation related to the doubt about the product choice made by the customer (Sweeney et al., 2000). The cognitive dissonance is produced as a result of impulse buying behavior under the condition where the customers were usually provided incentives for behavioral engagement by the marketer (Coley \& Burgess, 2003). An impulsive online purchaser tends to experience post-purchase dissonance which is due to post-purchase anxiety of possible unexpected results (Telci et al., 2011).

H5: Impulse buying behavior is significantly and positively related to post-purchase cognitive dissonance.

\subsection{The Mediating Role of Impulse Buying Behavior}

According to Solomon et al. (2016), the purpose of sales promotion was designed to encourage instant purchase 
and product trials in a certain period, thus it triggers impulse buying behavior. The latest study by Sundström et al. (2019) also suggested that some types of sales promotion, such as free shipping and discounted price for limited time generates impulse buying. Manufacturers and retailers are showing their intensive interest to understand consumer behavior in terms of impulse buying. Although, sales promotion including low product pricing is a useful method to generate positive feelings in consumers and make them excited to make a good deal, such feeling can lead to impulse buying (Campbell \& Diamond, 1990). Chandon et al. (2000) stated that sales promotion is positively influenced by buying behavior in both utilitarian and hedonic benefits. Many consumers set their shopping plans in advance and they search for advertisements for specific promotions. Although, promotions encourage unplanned purchases (Hui et al., 2013; Lu et al., 2019; Raghubir et al., 2004; Rook, 1987; Stilley et al., 2010). According to (Rook, 1987; Rook \& Hoch, 1985), the negative consequences such as dissatisfactions, guiltiness, breaking financial limits are the major causes of unplanned purchases. Many researchers have examined the negative utility experience when they evaluated the shopping experience of unplanned purchases (Hoch \& Loewenstein, 1991; Rook, 1987; Stilley et al., 2010). Although, previous researches (Festinger, 1957; Menasco \& Hawkins, 1978; Mowen, 1995) have defined cognitive dissonance as a psychological awkwardness that is linked with disappointments, guilt, and worries. Thus, the above concept evidence that impulse buying behavior may have a mediating effect between the relationship of sales promotion and post-purchase cognitive dissonance.

It is stated by Kaufmann et al. (2016), that those customers who have a greater attachment with brands are more likely to buy a particular product of that brand, whether it is original or fake. A prior study has examined that emotional attachment with brands becomes high when customers show impulse buying behavior (Horváth \& Birgelen, 2015). According to Roberts \& Jones, (2001), anxiety enhances impulse buying behavior. Furthermore, individuals who are strongly attached to brands spend more time and money for particular brands (C. W. Park et al., 2010). Meanwhile, Telci et al. (2011), have claimed that online impulsive purchasers always tend to experience post-purchase dissonance which is due to postpurchase anxiety of possible unpredicted results. Therefore, in the above sections, we have clarified that emotional brand attachment has a direct connection with impulse buying behavior, and impulse buying is directly associated with post-purchase cognitive dissonance. So, we assume that there may be a mediating relationship of impulse buying between emotional brand attachment and post-purchase cognitive dissonance. Thus, based on the above argument we proposed the following hypotheses.
H6a: Impulse buying behavior significantly and positively mediates the relationship between sales promotion and postpurchase cognitive dissonance.

H6b: Impulse buying behavior significantly and negatively mediates the relationship between emotional brand attachment and post-purchase cognitive dissonance.

\subsection{The Moderating Role of Gender}

The current study also examined the moderating role of gender between the relationship of sales promotion, emotional brand attachment, and impulse buying behavior with post-purchase cognitive dissonance. It is stated by Qi et al. (2015), that female customers are more likely to attach with smartphone brands. Eventually, in order to show the deep female attachment with brands, female customers would show higher impulsive attention to purchase smartphones. As such, females usually develop the brand attachment once they confirm that their early expectations relating to communication functions. Therefore, it seems that the brand attachment of male and female consumers is developed for different reasons (Hew et al., 2017). Various studies have claimed that women are more involved in promotional activities and the overall use of coupons compared to men (Blau \& Devaro, 2007; Harmon \& Jeanne Hill, 2003). However, little research has explained about this behavior. Out of both the genders, the females are more impulsive purchasers and they spend more time on store shopping. They usually show careful behavior while purchasing and have a preference related to fashion, expression, and emotion on impulse. Males are more selfobsessed and purchase useful products like electronics and sports instantly (Azam et al., 2012; Singh \& Goyal, 2009). Ekeng \& Lifu (2012) examined the impact of demographic features of consumers on the impulse buying behavior and they found gender as negatively related to impulse buying. A prior study revealed that females were ahead than males in displaying cognitive dissonance over making an impulse buying (Coley \& Burgess, 2003). In contrast, Fu et al. (2003) suggest that men are more impulsive than women. Hence, based on this discussion we proposed the following hypothesis.

H7: Gender is significantly and positively moderate between the relationship of sales promotion and post-purchase cognitive dissonance in a way that this relationship is stronger in females compared to males at a higher level of sales promotion.

H8: Gender has no moderating effect between the relationship of impulse buying behavior and post-purchase cognitive dissonance in a way that this relationship is weaker at a higher level of sales promotion.

H9: Gender has no moderating effect between the relationship of emotional brand attachment and postpurchase cognitive dissonance in a way that this relationship is weaker at a higher level of sales promotion. 


\section{Method}

\subsection{Data collection}

In this study, we have examined consumer purchase behavior toward Pakistani retail brands. The study is descriptive in nature and conducted by using a cross-sectional survey method. The data was collected by distributing self-administered questionnaires among retail consumers in Pakistan. The respondents of the study were professionals and students including (managers, professors, and senior officials); they were requested to provide the specific name of a favorite retail brand that they had at least a minimum level of attachment. An online survey link of questionnaires was emailed to all respondents and requested them to send it back to the author after completion.

\subsection{Sample Characteristics}

Although, a total of 378 questionnaires were distributed among the respondents. In the end, we received only 289 filled questionnaires. However, after completing the survey we excluded 33 questionnaires due to incomplete and inaccurate responses. The samples of 256 questionnaires were used for the final analysis. The demographic profiles of the respondents were: $44.5 \%$ were males and $55.5 \%$ females. For occupation, $47 \%$ were professionals and $53 \%$ were students. The educational backgrounds of the respondents were: $27 \%$ of students had an undergraduate degree, $58 \%$ had a master's degree and 15\% had a doctoral degree. Most of the respondents income reported in this range: less than Rs.20,000 (30.9\%), Rs.21,000- Rs.50,000 (43\%), and Rs.51,000 and above (26.2\%). In terms of age group, $27.4 \%$ were in the age group of $16-24,38.1 \%$ were in the age group of $25-44$, and $20.6 \%$ were in the age group of $45-64$.

\subsection{Measures}

To test the hypotheses, we developed a questionnaire. The measurement items were adapted from the previous literature. The five-point Likert scale was used to measure each item ranging from " $1=$ strongly disagree" to " $5=$ strongly agree". Sales promotion was adapted from the previous literature (Oly Ndubisi \& Tung Moi, 2006), and it was assessed by a six-items scale. Emotional brand attachment is used to measure the emotional attachment of consumers with a particular brand; it consists of five-items scales and designed by (Marka et al., 2019). Meanwhile, impulse buying behavior is also adapted from previous literature and designed by (Rook \& Fisher, 1995). It consists of a nine-item scale and describes the unplanned purchase behavior of consumers. Post-purchase cognitive dissonance is another variable that describes consumer behavior after the final purchase. Post-purchase cognitive dissonance consists of a four-items scale and it is designed by (Saleh, 2012).

\section{Analysis and Results}

\subsection{Measurement Model}

In this study, we used the Smart PLS (PLS-SEM) software to explore the research hypotheses. To evaluate the reliability and validity of the constructs, a multi-factor analysis was conducted (Gerbing \& Anderson, 1988). The coefficient value of reliability is as follows: 0.79 for impulse buying behavior, 0.71 for sales promotion, 0.76 for emotional brand attachment, 0.70 for post-purchase cognitive dissonance. The confirmatory factor analysis (CFA) resulted in the loading factor for every construct in the research model which is above the expected value of 0.50 (Arbuckle, 2016), thus the contribution of each indicator to the constructed variable is accepted. Composite reliability and average variance extracted exceed the standard recommended value 0.50 in prior literature (Fornell \& Larcker, 1981). Discriminant validity was proven by the fact that the average variance extracted of each latent construct must surpass the square correlation between each pair of constructs (Fornell \& Larcker, 1981). The results of standardized root mean square residual $(\mathrm{SRMR})=0.09$; normed index fit $(\mathrm{NIF})=0.557$ and chi-square $\left(X^{2}\right)=951.786$ shows the adequate fitness of the measurement model.

$$
\mathrm{AVE}=\frac{\sum \lambda^{2}}{\mathrm{~N}} \quad \mathrm{C} \cdot \mathrm{R}=\frac{\left(\sum \lambda\right)^{2}}{\left(\sum \lambda\right)^{2}+\sum\left(1-\lambda^{2}\right)}
$$

In the above equation, AVE is the average variance extracted, C.R is the composite reliability, $\Sigma \lambda$ is the sum of the factor loading, $\lambda^{2}$ is the square of the factor loading, $(\Sigma \lambda)^{2}$ is the square of "sum of factor loading" and $\Sigma\left(\lambda^{2}\right)$ is the sum of "square of factor loading.

\subsection{Structural Model}

In the next stage of analysis, structural equation modeling (SEM) was adopted to test the hypotheses by using Smart PLS. Table 1 describes the descriptive characteristics and inter-correlation among the variables. Furthermore, Table 2 shows the factor loading items including composite reliability and average variance extracted. Meanwhile, Table 3 and 4 explains the direct/indirect effects and the results of hypotheses. We used regression tools to verify the hypotheses. The $\mathrm{R}^{2}$ value refers to the percentage with which the exogenous variable explains the variation in the endogenous variables. Falk \& B. Miller (1992) suggested that the value of $\mathrm{R}^{2}$ should be greater than the standard value of 0.10 to be statistically viable. As shown in Figure 1, the explained variance is $17.6 \%$ is for impulse buying behavior and $32.5 \%$ is for post-purchase cognitive dissonance. All of the $\mathrm{R}^{2}$ values are exceeded the minimum value of 0.10 . 


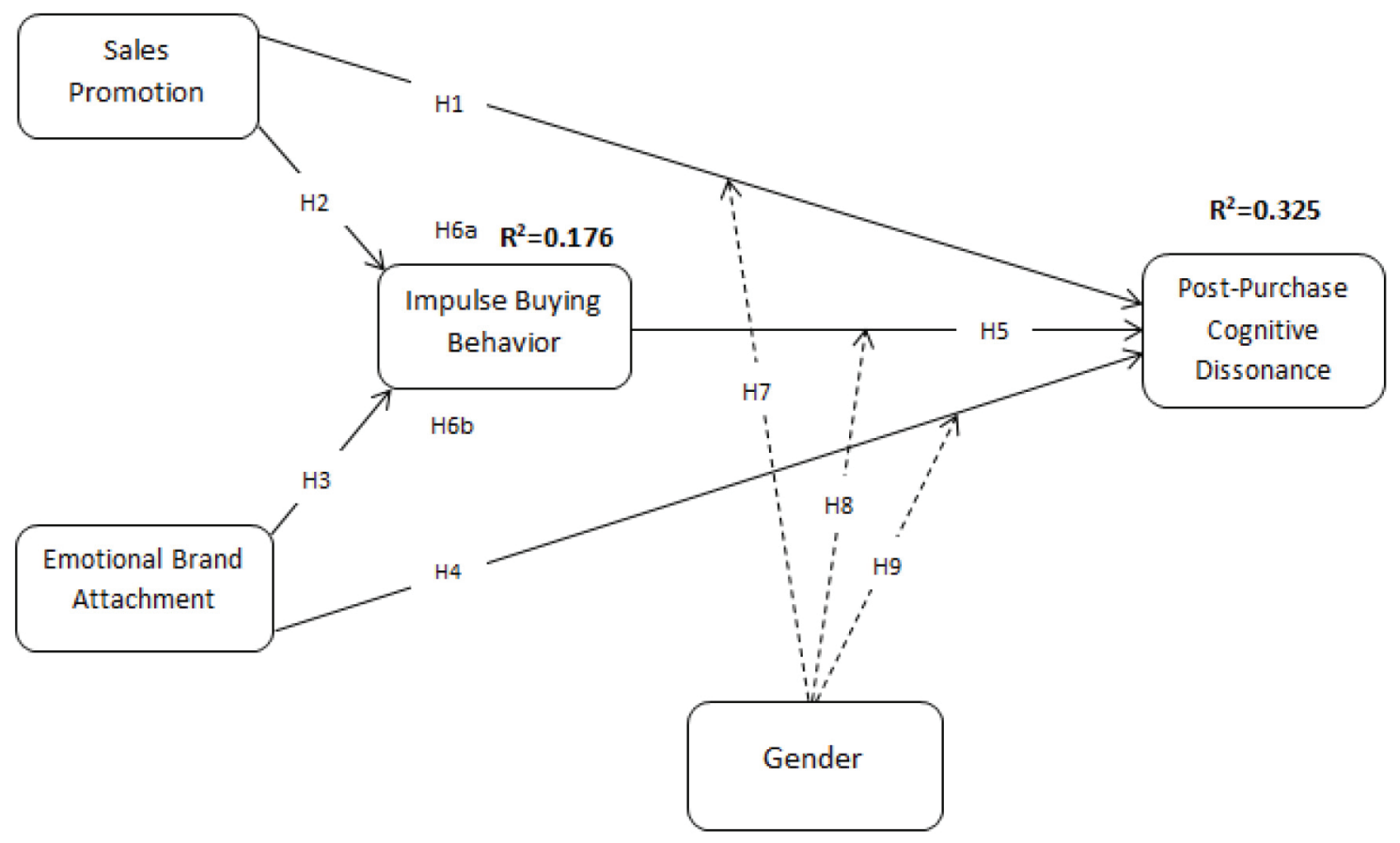

Figure 1: Conceptual Framework

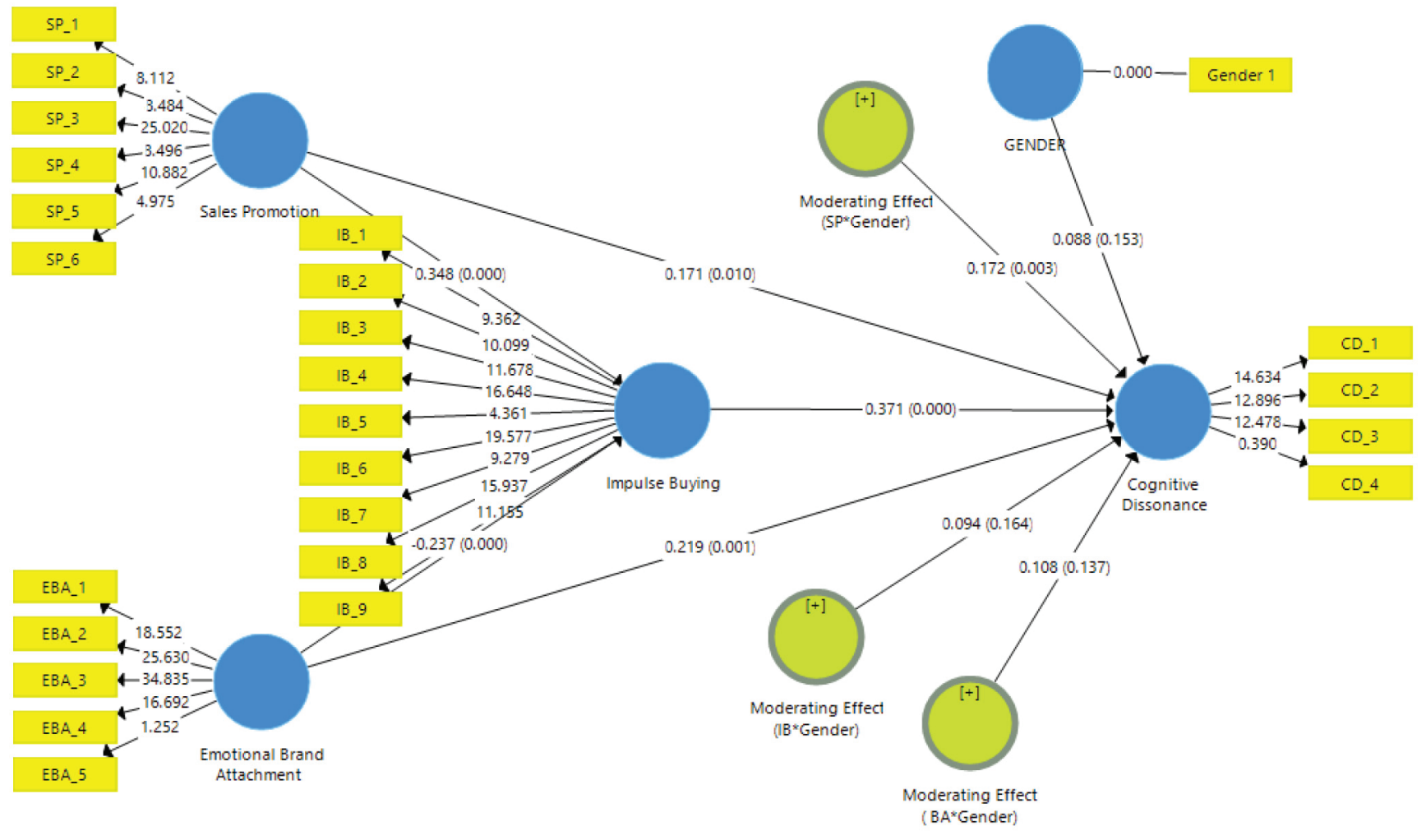

Figure 2: $p$-values and coefficient values 
Table 1: Correlation Matrix

\begin{tabular}{|c|c|c|c|c|c|c|c|c|c|c|}
\hline $\begin{array}{l}\text { S. } \\
\text { No }\end{array}$ & Variable & Mean & SD & 1 & 2 & 3 & 4 & 5 & 6 & 7 \\
\hline 1 & Impulse buying behavior & 2.71 & 0.70 & 1 & & & & & & \\
\hline 2 & Sales promotion & 2.88 & 0.65 & $.381^{\star *}$ & 1 & & & & & \\
\hline 3 & Emotional brand attachment & 3.83 & 0.61 & $-.247^{* *}$ & $-.206^{* *}$ & 1 & & & & \\
\hline 4 & Cognitive dissonance & 3.30 & 0.72 & .233 & $.167^{* *}$ & -.046 & 1 & & & \\
\hline 5 & Gender & 0.34 & 0.28 & .144 & -.012 & $-.075^{\star}$ & $.122^{\star *}$ & 1 & & \\
\hline 6 & Income & 1.95 & 0.76 & .099 & -.116 & -.083 & -.025 & .188 & 1 & \\
\hline 7 & Education & 1.90 & 0.49 & $-.108^{*}$ & -0.70 & -.021 & .080 & .092 & -.066 & 1 \\
\hline
\end{tabular}

** Correlation is significant at the 0.01 level, $p<.01$

* Correlation is significant at the 0.05 level, $p<.05$

Table 2: Direct, indirect and Interaction effect

\begin{tabular}{|c|c|c|c|c|c|c|}
\hline \multirow{3}{*}{ Effect of } & \multicolumn{6}{|c|}{ Effect On } \\
\hline & \multicolumn{3}{|c|}{ Impulse Buying } & \multicolumn{3}{|c|}{$\begin{array}{c}\text { Post-Purchase cognitive } \\
\text { dissonance }\end{array}$} \\
\hline & Direct & Indirect & Total & Direct & Indirect & Total \\
\hline Sales promotion & $0.348^{* *}$ & - & $0.348^{* *}$ & $0.171^{* *}$ & $0.129^{*}$ & $0.300^{* *}$ \\
\hline Emotional brand attachment & -0.237 & - & -0.237 & $0.219^{* *}$ & -0.088 & $0.131^{*}$ \\
\hline Impulse buying behavior & & & & $0.371^{* *}$ & - & $0.371^{* *}$ \\
\hline \multicolumn{7}{|l|}{ Interaction relationships: } \\
\hline Gender $\times$ SP $\rightarrow$ Cognitive dissonance & & & & $0.172^{* *}$ & - & $0.172^{* *}$ \\
\hline Gender $\times$ IBB $\rightarrow$ Cognitive dissonance & & & & 0.094 & - & 0.094 \\
\hline Gender $\times$ EBA $\rightarrow$ Cognitive dissonance & & & & 0.108 & - & 0.108 \\
\hline
\end{tabular}

Note: one-tailed test of significance.

${ }^{*} p<0.05$.

${ }^{* *} p<0.01$.

Regarding Hypothesis 1, results show that there was a positive and significant relationship between sales promotion and post-purchase cognitive dissonance $(\beta=0.171$, $p=0.010)$. Hence H1 supported this study. In the support of hypothesis 2 , the relationship between sales promotion and impulse buying behavior was significant and in the hypothesized direction $(\beta=0.348, p=0.000)$. For hypothesis 3 , the emotional brand attachment was significantly related to impulse buying behavior and negatively as hypothesized $(\beta=0.348, p=0.000)$. In the favor of hypothesis 4 , the relationship between emotional brand attachment and postpurchase cognitive dissonance $(\beta=0.219, p=0.001)$, as well as the relationship between impulse buying behavior and post-purchase cognitive behavior $(\beta=0.371, p=0.000)$ were both significant and positive as hypothesized.

\subsection{The Direct and Indirect Effect}

In Table 2, we presented the direct, indirect, and total effects of the predictor variables. For H6a and H6b we hypothesized impulse buying behavior as a mediating variable between sales promotion-postpurchase cognitive behavior relationships and emotional brand attachment- post-purchase cognitive dissonance relationship. Our findings showed contributing results for both H6a and H6b. The sales promotion is positively directly related to post-purchase cognitive behavior $(\beta=0.171, \quad p=0.010) ;$ moreover, the bootstrap estimations indicate that sales promotion influences postpurchase cognitive behavior $(\beta$ (indirect effect) $=0.129$; $p=0.000$ ) indirectly through impulse buying behavior. 
Table 3: Factor Loading of Items

\begin{tabular}{|c|c|c|c|c|c|}
\hline Variables & Construct & Indicator Loading & CR & AVE & Cronbach's Alpha \\
\hline \multirow{9}{*}{ Impulse Buying Behavior } & IBB1 & 0.59 & \multirow{9}{*}{0.84} & \multirow{9}{*}{0.57} & \multirow{9}{*}{0.79} \\
\hline & IBB2 & 0.61 & & & \\
\hline & IBB3 & 0.63 & & & \\
\hline & IBB4 & 0.67 & & & \\
\hline & IBB5 & 0.76 & & & \\
\hline & IBB6 & 0.71 & & & \\
\hline & IBB7 & 0.53 & & & \\
\hline & IBB8 & 0.70 & & & \\
\hline & IBB9 & 0.60 & & & \\
\hline \multirow{6}{*}{ Sales Promotion } & SP1 & 0.63 & \multirow{6}{*}{0.80} & \multirow{6}{*}{0.51} & \multirow{6}{*}{0.71} \\
\hline & SP2 & 0.58 & & & \\
\hline & SP3 & 0.80 & & & \\
\hline & SP4 & 0.62 & & & \\
\hline & SP5 & 0.66 & & & \\
\hline & SP6 & 0.52 & & & \\
\hline \multirow{5}{*}{$\begin{array}{l}\text { Emotional Brand } \\
\text { Attachment }\end{array}$} & EBA1 & 0.79 & \multirow{5}{*}{0.84} & \multirow{5}{*}{0.55} & \multirow{5}{*}{0.76} \\
\hline & EBA2 & 0.84 & & & \\
\hline & EBA3 & 0.87 & & & \\
\hline & EBA4 & 0.79 & & & \\
\hline & EBA5 & 0.68 & & & \\
\hline \multirow{4}{*}{$\begin{array}{l}\text { Post-Purchase Cognitive } \\
\text { Dissonance }\end{array}$} & PPCB1 & 0.76 & \multirow{4}{*}{0.71} & \multirow{4}{*}{0.53} & \multirow{4}{*}{0.70} \\
\hline & PPCB2 & 0.78 & & & \\
\hline & PPCB3 & 0.79 & & & \\
\hline & PPCB4 & 0.19 & & & \\
\hline
\end{tabular}

Table 4: Testing Hypotheses

\begin{tabular}{|c|c|c|c|c|c|}
\hline \multicolumn{2}{|c|}{ Hypotheses } & \multirow{2}{*}{$\frac{p \text {-values }}{0.010}$} & \multirow{2}{*}{$\begin{array}{c}\text {-values } \\
2.598\end{array}$} & \multirow{2}{*}{$\begin{array}{c}\text { Type of relationship } \\
+\end{array}$} & \multirow{2}{*}{$\begin{array}{l}\text { Sig. }<0.05 \\
\text { Supported }\end{array}$} \\
\hline $\mathrm{H} 1$ & $\mathrm{SP} \rightarrow \mathrm{PPCD}$ & & & & \\
\hline $\mathrm{H} 2$ & $\mathrm{SP} \rightarrow \mathrm{IBB}$ & 0.000 & 6.751 & + & Supported \\
\hline $\mathrm{H} 3$ & $\mathrm{EBA} \rightarrow \mathrm{IBB}$ & 0.000 & 3.806 & - & Supported \\
\hline $\mathrm{H} 4$ & $\mathrm{EBA} \rightarrow \mathrm{PPCD}$ & 0.001 & 3.251 & + & Supported \\
\hline H5 & $\mathrm{IB} \rightarrow \mathrm{PPCD}$ & 0.000 & 4.761 & + & Supported \\
\hline $\mathrm{H} 6 \mathrm{a}$ & $\mathrm{SP} \rightarrow \mathrm{IB} \rightarrow \mathrm{PPCD}$ & 0.000 & 3.684 & + & Supported \\
\hline $\mathrm{H} 6 \mathrm{~b}$ & $\mathrm{EBA} \rightarrow \mathrm{IB} \rightarrow \mathrm{PPCD}$ & 0.002 & 3.107 & - & Supported \\
\hline $\mathrm{H} 7$ & Gender $\times$ SP $\rightarrow$ PPCD & 0.004 & 2.924 & + & Supported \\
\hline $\mathrm{H} 8$ & Gender $\times$ IB $\rightarrow$ PPCD & 0.170 & 1.373 & + & Not Supported \\
\hline $\mathrm{H} 9$ & Gender $\times$ EBA $\rightarrow$ PPCD & 0.124 & 1.541 & + & Not Supported \\
\hline
\end{tabular}




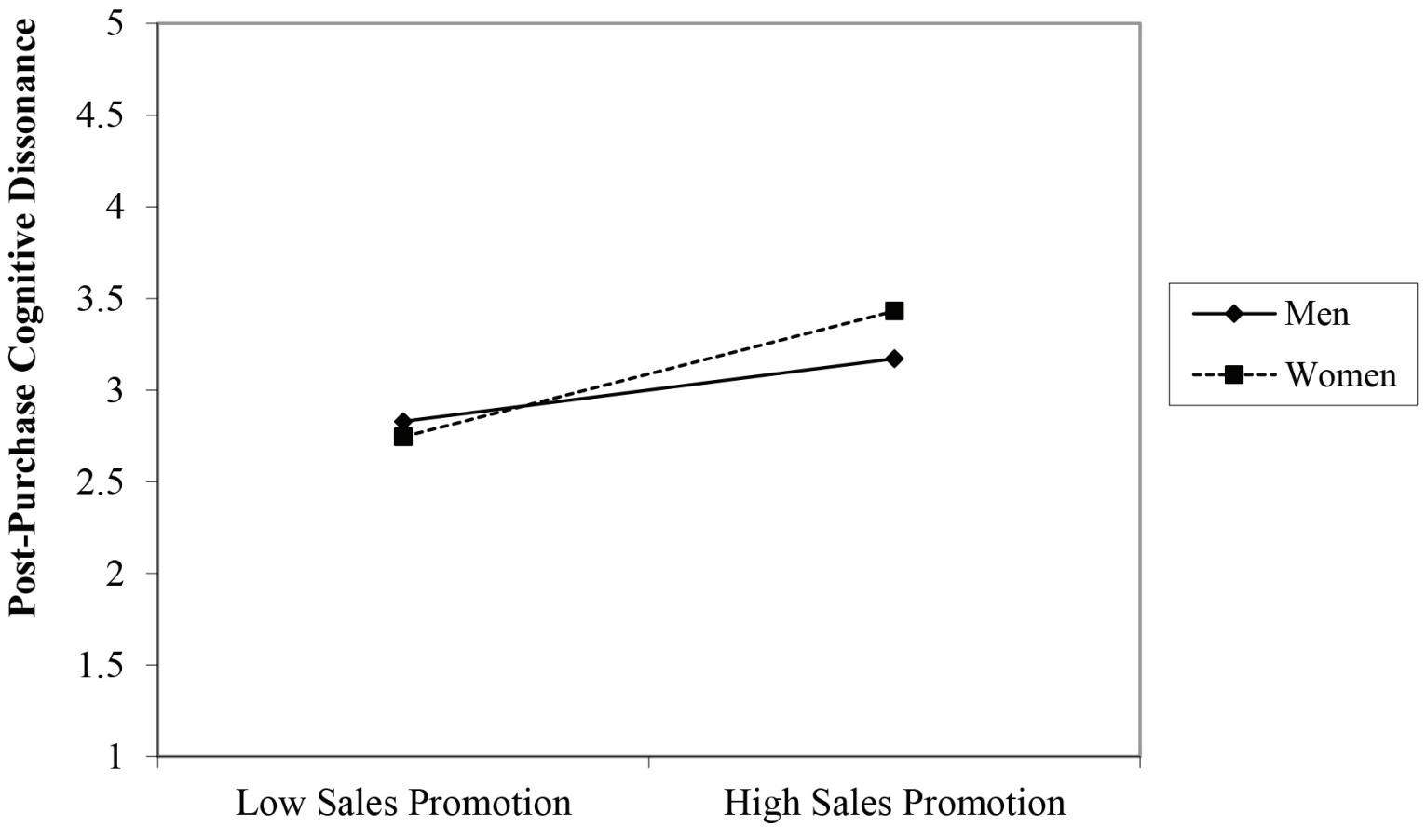

Figure 3: Simple slope analysis

Hence, impulse buying behavior partially mediates between the relationship of sales promotion and post-purchase cognitive dissonance. Emotional brand attachment is direct positively associated with post-purchase cognitive dissonance $(\beta=0.219, p=0.001)$; likewise, the bootstrap estimation show that emotional brand attachment affect post-purchase cognitive dissonance ( $\beta$ (indirect effect) $=-0.088 ; p=0.002$ ) indirectly through impulse buying behavior.

So, impulse buying behavior is partially mediating the relationship between emotional brand attachment and postpurchase cognitive dissonance. In our review of the literature, we did not find any study that investigates the mediating role of impulse buying behavior among any variables.

\subsection{Moderating Results}

The gender was performed as a moderator to examine the interaction effect between each relationship. As we hypothesized the relationship, the results in Table 4 showed significant moderating results between the relationship of sales promotion and post-purchase cognitive dissonance $(\beta=0.172$, $p=0.004$ ). Hence, it proves that $\mathrm{H} 7$ has supported the study. Although, the gender moderates insignificantly among the relationship of impulse buying behavior and post-purchase cognitive dissonance $(\beta=0.094, p=0.170)$. Similarly, the insignificant moderating results were found between the relationship of emotional brand attachment and post-purchase cognitive dissonance $(\beta=0.108, p=0.124)$. Consequently, H8 \& H9 have not supported the study. As can be seen in Figure 3, the line labeled for females has a steeper and positive slope when compared to males. Thus, we can propose that in comparison with males the post-purchase cognitive dissonance for females will be stronger in high sales promotion.

\section{Discussion and Conclusion}

The main objective of this research is to investigate the effect of sales promotion and emotional brand attachment on post-purchase cognitive dissonance, taking into account the mediator role of impulse buying behavior. The current study reveals several theoretical contributions. This study provides support for the effect of sales promotion on the impulse buying behavior and post-purchase cognitive dissonance (H1 \& H2 supported). By comparing these results with previous research, it can be said that the findings are consistent with the results of (Wang et al., 2019). Furthermore, we found a significant and positive relationship between emotional brand attachment and post-purchase cognitive dissonance (H3 supported) which is consistent with the findings of (Jamwal \& Soodan, 2014). Although, contrary to previous research (Japutra et al., 2019) emotional brand attachment has a negative impact on impulse buying behavior (H4 supported).

Impulse buying behavior has received considerable attention towards marketing literature (Mohan et al., 2013; 
E. J. Park et al., 2006; Roberts \& Jones, 2001). Our study shows that impulse buying behavior enhances post-purchase cognitive dissonance which is consistent with the results of (Coley \& Burgess, 2003; George \& Yaoyuneyong, 2010) (H5 supported). Chandon et al. (2000) claimed that many consumers set their purchasing plans and they are in search of promotional ads in advance. Although, promotions encourage unplanned purchases. Many researchers have examined the bad shopping experience when they evaluated the shopping experience of impulse buying (Hoch \& Loewenstein, 1991; Hui et al., 2013; Stilley et al., 2010). Indeed, our findings confirm that impulse buying behavior significantly mediates the relationship of two predictor variables (sales promotion $\&$ emotional brand attachment) and post-purchase cognitive dissonance (H6a \& H6b supported). The result of our research claims that gender is a potential moderator between the relationship of sales promotion and post-purchase cognitive dissonance.

The discussion in this article has given an overview to understand the importance of consumer buying behavior in today's competitive environment. Despite its rising importance, the literature is missing to explore the direct effect of sales promotions and emotional brand attachment on post-purchase cognitive dissonance. However, to the best of our knowledge, the limited numbers of studies have investigated the mediating role of impulse buying behavior in consumer research. The authors tried to fill this gap. The finding of moderation suggests that under a high sales promotion environment the post-purchase cognitive dissonance is stronger for women as compared to men.

\subsection{Managerial Implication}

Our research provides several implications for marketing and brand managers. First, the linkage between sales promotion and impulse buying behavior indicates that managers should focus on promotional activities just to gain customer attention because product promotion enhances the consumers' impulsiveness. As it is described by many authors that promotional activities encourage unplanned purchases (Hui et al., 2013; Raghubir et al., 2004; Rook, 1987). Although, managers should design their promotional activities that could reduce the post-purchase anxieties and discomfort of consumers. The marketers should represent the shift of customer's psychological states by using emotional branding as a key tool which touches the emotional chords of consumers and can overcome the post-purchase dissonance behavior. The findings of this study also suggest that most of the customers show their happiness and satisfaction after post-purchase decisions when they are emotionally attached to a specific brand. The best suggestion for managers is to diminish the cognitive dissonance by offering quality services, guarantees, and provide detailed information about how to use the products. In summary, the linkage between sales promotion, emotional brand attachment, impulse buying behavior, and post-purchase cognitive dissonance, as found in this study, could be useful insights for innovative marketing strategies.

\subsection{Limitation and Future Research}

Based on the research findings, several new possibilities are discovered for future research. First, in Figure 1 the explained variance for impulse buying $\left(\mathrm{R}^{2}=17.6 \%\right)$, is slightly above $10 \%$ the minimum standard value defined by (Falk \& B. Miller, 1992). It means that some latent variables could be added to advance the explanatory power of impulse buying behavior and post-purchase cognitive dissonances, such as other brand-related emotional factors and market-based incentive policies. The current study investigated consumer buying behavior in terms of retail brands. In the future, the existing model could be replaced by the researchers for online fashion brands. The data was cross-sectional, which prevents the ability to draw causal implications. Future research may be longitudinal, so the researchers can examine the impulsive behavior of consumers over a period, and experiment and collect data at multiple points in time which may better direct causality among the studied constructs. There is another limitation involved, the selection of a single geographical context of Pakistani consumers as a sample frame. According to Potluri \& Johnson (2020), consumers seem to have a relative preference for products from their own country. Therefore, based on cultural preferences the data could be collected from different geographical locations for the stability of findings and generalizability.

\section{References}

Ali Khan, M., \& Sohaib Zubair, S. (2019). Impact of sales promotion on impuls buying behavior: A case of modern trade, Pakistan. Governance and Management Review, 4(1), 38-53.

Arbuckle, J. L. (2016). IBM SPSS Amos 21: User's Guide. Retrieved May 5, 2020 from: https://b-ok.asia/book/2983700/ b9a387? regionChanged $=\&$ redirect $=5175906$

Azam, R., Muhammad, D., \& Akbar, S. (2012). Consumption style among young adults toward their shopping behavior:an empirical study in Pakistan, MPRA Paper 42369, University Library of Munich. Retrieved July 15, 2020 from: https://ideas. repec.org/p/pra/mprapa/42369.html.

Bawa, A., \& Kansal, P. (2008). Cognitive Dissonance and the Marketing of Services: Some Issues. Journal of Services Research, 8(2), 31-51. https://papers.ssrn.com/sol3/papers. cfm?abstract_id $=2062700$ 
Beatty, S. E., \& Ferrell, M. E. (1998). Impulse buying: Modeling its precursors. Journal of Retailing, 74(2), 169-191. https://doi. org/10.1016/S0022-4359(99)80092-X

Belk, R. W. (1988). Possessions and the Extended Self. Journal of Consumer Research, 15(2), 139. https://doi. org/10.1086/209154

Blattberg, R. C., \& Neslin, S. A. (1990). Sales Promotion: Concepts, Methods, and Strategies. Retrieved June 18, 2020 from:https:// books.google.com.pk/books/about/Sales_Promotion. html?id=CjIPAQAAMAAJ\&redir_esc $=\mathrm{y}$

Blau, F. D., \& Devaro, J. (2007). New Evidence on Gender Differences in Promotion Rates: An Empirical Analysis of a Sample of New Hires. Retrieved June 10, 2020 from: https:// digitalcommons.ilr.cornell.edu/articles/113

Bowlby, J. (1977). The making and breaking of affectional bonds: I. Aetiology and psychopathology in the light of attachment theory. British Journal of Psychiatry, 130(3), 201-210. https:// doi.org/10.1192/bjp.130.3.201

Bozaci, I. (2020). The Effect of Boredom Proneness on Smartphone Addiction and Impulse Purchasing: A Field Study with Young Consumers in Turkey. The Journal of Asian Finance, Economics and Business, 7(7), 509-517. https://doi.org/10.13106/ jafeb.2020.vol7.no7.509

Campbell, L., \& Diamond, W. D. (1990). Framing and sales promotions: The characteristics of a "good deal." Journal of Consumer Marketing, 7(4), 25-31. https://doi.org/10.1108/ EUM0000000002586

Chandon, P., Wansink, B., \& Laurent, G. (2000). A Benefit Congruency Framework of Sales Promotion Effectiveness. Journal of Marketing, 64(4), 65-81. https://doi.org/10.1509/ jmkg.64.4.65.18071

Chaudhuri, A., \& Holbrook, M. B. (2001). The Chain of Effects from Brand Trust and Brand Affect to Brand Performance: The Role of Brand Loyalty. Journal of Marketing, 65(2), 81-93. https://doi.org/10.1509/jmkg.65.2.81.18255

Coley, A., \& Burgess, B. (2003). Gender differences in cognitive and affective impulse buying. Journal of Fashion Marketing and Management, 7(3), 282-295. https://doi. org/10.1108/13612020310484834

Dwayne B., A., \& Tasaki, L. H. (1992). The Role and Measurement of Attachment in Consumer Behavior. Journal of Consumer Psychology, 1(2), 155-172. https://doi.org/10.1016/S10577408(08)80055-1

Egan, L. C., Santos, L. R., \& Bloom, P. (2007). The origins of cognitive dissonance: Evidence from children and monkeys. Psychological Science, 18(11), 978-983. https://doi. org/10.1111/j.1467-9280.2007.02012.x

Ekeng, A. B., \& Lifu, F. L. (2012). Effect of demographic characteristics on consumer impulse buying among consumers of calabar municipality, cross river state. Academic Research International, 3(2), 568-574.

Falk, R., \& B. Miller, N. (1992). A Primer for Soft Modeling. Akron, $\mathrm{OH}$ : University of Akron Press
Festinger, L. (1957). A Theory of Cognitive Dissonancee. Palo Alto, CA: Stanford University Press.

Fornell, C., \& Larcker, D. F. (1981). Evaluating Structural Equation Models with Unobservable Variables and Measurement Error. Journal of Marketing Research, 18(1), 39. https://doi. org/10.2307/3151312

Fournier, S. (1998). Consumers and their brands: Developing relationship theory in consumer research. Journal of Consumer Research, 24(4), 343-373. https://doi. org/10.1086/209515

Fu, J., Mai, B., Sheng, G., Zhang, G., Wang, X., Peng, P., Xiao, X., Ran, R., Cheng, F., Peng, X., Wang, Z., \& Tang, U. W. (2003). Persistent organic pollutants in environment of the Pearl River Delta, China: An overview. Chemosphere, 52(9), 1411-1422. https://doi.org/10.1016/S0045-6535(03)00477-6

George, B. P., \& Yaoyuneyong, G. (2010). Impulse buying and cognitive dissonance: A study conducted among the spring break student shoppers. Young Consumers, 11(4), 291-306. https://doi.org/10.1108/17473611011093925

Gerbing, D. W., \& Anderson, J. C. (1988). An Updated Paradigm for Scale Development Incorporating Unidimensionality and Its Assessment. Journal of Marketing Research, 25(2), 186. https://doi.org/10.2307/3172650

Harmon, S. K., \& Jeanne Hill, C. (2003). Gender and coupon use. Journal of Product \& Brand Management, 12(3), 166-179. https://doi.org/10.1108/10610420310476924

Hartley, S. W., \& Cross, J. (1988). How sales promotion can work for and against you. In Journal of Consumer Marketing (Vol. 5, Issue 3, pp. 35-42). MCB UP Ltd. https://doi.org/10.1108/ eb008230

Hausman, A. (2000). A multi-method investigation of consumer motivations in impulse buying behavior. Journal of Consumer Marketing, 17(5), 403-419. https://doi. org/10.1108/07363760010341045

Helga, D. (2001). Impulse buying in ordinary and "compulsive" consumers. Conflict and Tradeoffs in Decision Making, 110 135. Retrieved July 10, 2020 from: https://psycnet.apa.org/ record/2002-00594-004

Hew, J. J., Badaruddin, M. N. B. A., \& Moorthy, M. K. (2017). Crafting a smartphone repurchase decision making process: Do brand attachment and gender matter? Telematics and Informatics, 34(4), 34-56. https://doi.org/10.1016/j. tele.2016.12.009

Hoch, S. J., \& Loewenstein, G. F. (1991). Time-Inconsistent Preferences and Consumer Self-Control. Journal of Consumer Research, 17(4), 492. https://doi.org/10.1086/208573

Horváth, C., \& Birgelen, M. (2015). The role of brands in the behavior and purchase decisions of compulsive versus noncompulsive buyers. European Journal of Marketing, 49, 2-21. https://doi.org/10.1108/EJM-10-2012-0627

Hui, S. K., Inman, J. J., Huang, Y., \& Suher, J. (2013). The Effect of In-Store Travel Distance on Unplanned Spending: Applications 
to Mobile Promotion Strategies. Journal of Marketing, 77(2), 1-16. https://doi.org/10.1509/jm.11.0436

Inman, J. J., Dyer, J. S., \& Jia, J. (1997). Generalized Utility Model of on and Disappointment Regret Effects Valuation. Management Science, 16(2), 97-111. https://doi.org/10.2307/184213

Jamwal, M., \& Soodan, V. (2014). Emotional branding as tool for dissonance reduction: A strategy for competitive advantage . International Monthly Refereed Journal of Research In Management \& Technology, 3, 25-32. https:// www.researchgate.net/publication/259894156_Emotional_ Branding_As_Tool_For_Dissonance_Reduction_A_Strategy_For_Competitive_Advantage

Japutra, A., Ekinci, Y., \& Simkin, L. (2019). Self-congruence, brand attachment and compulsive buying. Journal of Business Research, 99, 456-463. https://doi.org/10.1016/j. jbusres.2017.08.024

Jobber, D., \& Lancaster, G. (2006). Selling and Sales Management ( $7^{\text {th }}$ ed.). Harlow, UK: Pearson Education.

Jones, M. A., Reynolds, K. E., Weun, S., \& Beatty, S. E. (2003). The product-specific nature of impulse buying tendency. Journal of Business Research, 56(7), 505-511. https://doi.org/10.1016/ S0148-2963(01)00250-8

Kaufmann, H. R., Petrovici, D. A., Filho, C. G., \& Ayres, A. (2016). Identifying moderators of brand attachment for driving customer purchase intention of original vs counterfeits of luxury brands. Journal of Business Research, 69(12), 57355747. https://doi.org/10.1016/j.jbusres.2016.05.003

Kessous, A., Roux, E., \& Chandon, J.-L. (2015). Consumer-Brand Relationships: A Contrast of Nostalgic and Non-Nostalgic Brands. Psychology \& Marketing, 32(2), 187-202. https://doi. org/10.1002/mar.20772

Kotler, P. (1997). Marketing Management: Analysis, Planning, Implementation, and Control. Retrieved July 10, 2020 from: https://books.google.com.pk/books/about/Marketing_ Management.html?id=r5duSQAACAAJ\&redir_esc $=y$

Loveland, K. E., Smeesters, D., \& Mandel, N. (2010). Still Preoccupied with 1995: The Need to Belong and Preference for Nostalgic Products. Journal of Consumer Research, 37(3), 393-408. https://doi.org/10.1086/653043

Lu, J., Zhang, Z., \& Jia, M. (2019). Does Servant Leadership Affect Employees' Emotional Labor? A Social InformationProcessing Perspective. Journal of Business Ethics, 159(2), 507-518. https://doi.org/10.1007/s10551-018-3816-3

Marka, E., Ve, A., Sadakati, M., Seçim, M., Üzerindeki, Y., Duygusal, E. :, Bağlılığının, M., \& Rolü, A. (2019). Ethical Brand Perceptions and Their Impact on Brand Loyalty and Brand Choice Intentions: Mediating Role of Emotional Brand Attachment. Journal of Yasar University (Vol. 14, Issue 56). https://dergipark.org.tr/en/pub/jyasar/556092

Matzler, K., Bidmon, S., \& Grabner-Kräuter, S. (2006). Individual determinants of brand affect: The role of the personality traits of extraversion and openness to experience. Journal of Product and Brand Management, 15(7), 427-434. https://doi. org/10.1108/10610420610712801

Menasco, M. B., \& Hawkins, D. I. (1978). A Field Test of the Relationship between Cognitive Dissonance and State Anxiety. Journal of Marketing Research, 15(4), 650. https://doi. org/10.2307/3150639

Mittal, B. (1989). A Theoretical Analysis of Two Recent Measures of Involvement. ACR North American Advances, NA-16. Retrieved July 12, 2020 from: https://www.acrwebsite.org/ volumes/6980/volumes/v16/NA-16/full

Mohan, G., Sivakumaran, B., \& Sharma, P. (2013). Impact of store environment on impulse buying behavior. European Journal of Marketing, 47(10), 1711-1732. https://doi.org/10.1108/EJM03-2011-0110

Mowen, J. C. (1995). Consumer Behavior (5 $5^{\text {th }}$ ed.). Englewood Cliffs, NJ: Prentice Hall.

Mugge, R., Schifferstein, H. N. J., \& Schoormans, J. P. L. (2010). Product attachment and satisfaction: Understanding consumers' post-purchase behavior. Journal of Consumer Marketing, 27(3), 271-282. https://doi.org/10.1108/07363761011038347

Nagadeepa, C., \& Tamil Selvi, J. (2015). Impact of Sale Promotion Techniques on Consumers' Impulse Buying Behaviour towards Apparels at Bangalore. Asian Journal of Management Sciences \& Education, 4(1), 116-124.

Oly Ndubisi, N., \& Tung Moi, C. (2006). Awareness and usage of promotional tools by Malaysian consumers: The case of low involvement products. Management Research News, 29, 2840. https://doi.org/10.1108/01409170610645420

Parboteeah, D. V., Valacich, S. J., \& Wells, J. (2009). The Influence of Website Characteristics on a Consumer's Urge to Buy Impulsively on JSTOR. Information Systems Research, 20(1), 60-78.

Park, C. W., Macinnis, D. J., Priester, J., Eisingerich, A. B., \& Iacobucci, D. (2010). Brand Attachment and Brand Attitude Strength: Conceptual and Empirical Differentiation of Two Critical Brand Equity Drivers. Journal of Marketing, 74(6), 1-17. https://doi.org/10.1509/jmkg.74.6.1

Park, E. J., Kim, E. Y., \& Forney, J. C. (2006). A structural model of fashion-oriented impulse buying behavior. Journal of Fashion Marketing and Management, 10(4), 433-446. https://doi. org/10.1108/13612020610701965

Potluri, R. M., \& Johnson, S. (2020). An Exploratory Research on Country-of-Origin and Its Impact on the UAE Consumers Buying Decisions. The Journal of Asian Finance, Economics and Business, 7(9), 455-466. https://doi.org/10.13106/ jafeb.2020.vol7.no9.455

Qi, J. Y., Qu, Q. X., Zhou, Y. P., \& Li, L. (2015). The impact of users' characteristics on customer lifetime value raising: Evidence from mobile data service in China. Information Technology and Management, 16(4), 273-290. https://doi.org/10.1007/s10799014-0200-6 
Raghubir, P., Inman, J. J., \& Grande, H. (2004). The three faces of consumer promotions. In California Management Review (Vol. 46, Issue 4). University of California Press. https://doi. org/10.2307/41166273

Roberts, J. A., \& Jones, E. (2001). Money attitudes, credit card use, and compulsive buying among American college students. Journal of Consumer Affairs, 35(2), 213-240. https://doi. org/10.1111/j.1745-6606.2001.tb00111.x

Rook, D. W. (1987). The Buying Impulse. The Journal of Consumer Research, 14(2), 189-199. https://www.psych.ualberta. ca/ msnyder/p486/read/files/R1987.pdf

Rook, D. W., \& Fisher, R. J. (1995). Normative Influences on Impulsive Buying Behavior. Journal of Consumer Research, 22(3), 305. https://doi.org/10.1086/209452

Rook, D. W., \& Hoch, S. J. (1985). Consuming Impulses. ACR North American Advances, NA-12. Retrieved July 10 , 2020 from: https://www.acrwebsite.org/volumes/6351/volumes/v12/ NA-12/full

Saleh, M. A. E. H. (2012). An Investigation of the Relationship between Unplanned Buying and Post-purchase Regret. International Journal of Marketing Studies, 4(4), p106. https:// doi.org/10.5539/ijms.v4n4p106

Schiffman, L. (1997). Consumer behavior (6th ed.) Upper Saddle River, N.J: Prentice Hall.

Singh, J., \& Goyal, B. B. (2009). Mobile Handset Buying Behavior of Different Age and Gender Groups. International Journal of Business and Management, 4(5). https://doi.org/10.5539/ijbm. v4n5p179

Sinha, I., \& Smith, M. F. (2000). Consumers' perceptions of promotional framing of price. Psychology and Marketing, 17(3), 257-275. https://doi.org/10.1002/(SICI)15206793(200003)17:3<257::AID-MAR4>3.0.CO;2-P

Sivadas, E., \& Venkatesh, R. (1995). An Examination of Individual and Object-Specific Influences on the Extended Self and Its Relation to Attachment and Satisfaction. Advances in Consumer Research, 22(1), 406-412.

Smith, J. B., \& Bristor, J. M. (1994). Uncertainty orientation: Expalaining diffeerences in purchase involvement and external search. Psychology and Marketing, 11(6), 587-607. https://doi. org/10.1002/mar.4220110606

Solomon, M., Marshall, G., \& Stuart, E. (2016). Marketing: Real People, Real Choices (9th ed.). London, UK: Pearson. J
Stern, H. (1962). The Significance of Impulse Buying Today. Journal of Marketing, 26(2), 59-62. https://doi.org/10.2307/1248439

Stilley, K. M., Inman, J. J., \& Wakefield, K. L. (2010). Planning to make unplanned purchases? The role of in-store slack in budget deviation. Journal of Consumer Research, 37(2), 264-278. https://doi.org/10.1086/651567

Straker, K., \& Wrigley, C. (2016). Emotionally engaging customers in the digital age: The case study of "Burberry love." Journal of Fashion Marketing and Management, 20(3), 276-299. https:// doi.org/10.1108/JFMM-10-2015-0077

Sundström, M., Hjelm-Lidholm, S., \& Radon, A. (2019). Clicking the boredom away: Exploring impulse fashion buying behavior online. Journal of Retailing and Consumer Services, 47, 150 156. https://doi.org/10.1016/j.jretconser.2018.11.006

Sweeney, J. C., Hausknecht, D., \& Soutar, G. N. (2000). Cognitive dissonance after purchase: A multidimensional scale. Psychology and Marketing, 17(5), 369-385. https:// doi.org/10.1002/(SICI)1520-6793(200005)17:5<369::AIDMAR1>3.0.CO;2-G

Taylor, S. E., \& Schneider, S. K. (1989). Coping and the Simulation of Events. Social Cognition, 7(2), 174-194. https://doi. org/10.1521/soco.1989.7.2.174

Telci, E. E., Maden, C., \& Kantur, D. (2011). The theory of cognitive dissonance: A marketing and management perspective. Procedia - Social and Behavioral Sciences, 24, 378-386. https://doi.org/10.1016/j.sbspro.2011.09.120

Thomson, M., MacInnis, D. J., \& Park, C. W. (2005). The ties that bind: Measuring the strength of consumers' emotional attachments to brands. Journal of Consumer Psychology, 15(1), 77-91. https://doi.org/10.1207/s15327663jcp1501_10

Vohs, K. D., \& Faber, R. J. (2007). Spent Resources: SelfRegulatory Resource Availability Affects Impulse Buying. Journal of Consumer Research, 33(4), 537-547. https://doi. org/10.1086/510228

Vongurai, R. (2020). Factors Affecting Customer Brand Preference toward Electric Vehicle in Bangkok, Thailand. The Journal of Asian Finance, Economics and Business, 7(8), 383-393. https://doi.org/10.13106/jafeb.2020.vol7.no8.383

Wang, L., Yan, Q., \& Chen, W. (2019). Drivers of purchase behavior and post-purchase evaluation in the Singles' Day promotion. Journal of Consumer Marketing, 36(6), 835-845. https://doi. org/10.1108/JCM-08-2017-2335 